DOI:

\title{
СИСТЕМА ОВЛАДЕНИЯ СТРАТЕГИЯМИ ЧТЕНИЯ В КУРСЕ РУССКОГО ЯЗЫКА КАК ИНОСТРАННОГО: ИЗ ОПЫТА СОЗДАНИЯ УЧЕБНИКА
}

\section{THE SYSTEM OF GAINING READING STRATEGIES IN \\ THE COURSE OF RUSSIAN AS A FOREIGN LANGUAGE: \\ THE EXPERIENCE OF CREATING THE TEXTBOOK}

\author{
Larisa Ignatjeva \\ Baltijas Starptautiskā akadēmija \\ larisa.ignatjeva@gmail.com
}

\begin{abstract}
ANOTĀCIJA
Raksta mērḳis - iepazīstināt ar lasišanas paṇēmienu apguves lingvodidaktisko sistēmu, kas îstenota 6.-9. klasei paredzētajos krievu valodas kā otrās svešvalodas mācību līdzekḷ komplektos „Vienkārši krieviski” (Просто по-русски), kuri tiek aprobēti Latvijas skolās.

Pētījuma metodes: zinātniskās literatūras analīzes, mācību procesa novērošana un analīze, testēšana, skolēnu un skolotāju anketēšana, sarunas.

Rakstā aktualizēta problēma, kas saistīta ar skolēnu lasītprasmes attīstību krievu valodas kā otrās svešvalodas apguves laikā, raksturoti piedāvātās lingvodidaktskās sistēmas principi un lasī̌anas prasmju apguves paṇēmieni, pamatota to izvēle.
\end{abstract}

Atslēgvārdi: kompetenču pieeja, krievu valoda kā svešvaloda, mācību grāmata, lasǐ̌̌anas paṇēmieni, lingvodidaktiskā sistēma

Key words: competence approach, Russian as a foreign language, school textbook, reading strategies, linguo-didactic system

В современном мире всё более отчётливо проявляется прямая зависимость между информационными компетенциями человека и качеством его жизни. Важнейшим каналом получения информации является 
чтение. Именно поэтому на этапе школьного образования компетенциям в области чтения уделяется большое внимание (Lasītprasmes mācīšana Eiropā 2011).

Цель автора данной статьи - разработать лингводидактическую систему овладения стратегиями чтения и представить ее в структуре школьного учебника по русскому языку как иностранному (далее: русский язык как иностранный - РКИ). Несмотря на то, что в начале XXI века информационно-коммуникационные технологии активно проникают во все сферы нашей жизни, учебник пока по-прежнему остается основным средством освоения иностранного языка в школе. Особую значимость он приобретает в эпоху смены парадигмы образования, так как лингводидактическая системность учебника помогает внедрять в практику работы школ новые подходы и инновационные образовательные технологии.

Современные тенденции в развитии европейского образования отражены в целом ряде документов Совета Европы (Lisbon European Council 2000, Memorandum on Lifelong Learning 2000, Council Conclusions 2011 и др.). В этих документах подчеркивается, что основной целью образования должно стать всестороннее развитие учащегося, которое находит выражение в его компетенциях. Под компетенциями понимаются базовые характеристики, охватывающие когнитивную, психомоторную и мотивационную сферы личности и определяющие её способность успешно действовать в профессиональных или жизненных ситуациях (Спенсер, Спенсер 2010). Компетентностный подход является ответом Генерального Директората Европейской Комиссии по образованию на потребности современного общества и отражает сущность образовательной политики в школах Европейского Союза.

При разработке лингводидактической системы развития компетенций в области чтения в школьном курсе РКИ мы использовали следующие методы: анализ научной литературы, наблюдение за учебным процессом и его анализ, тестирование, анкетирование учеников и учителей, беседы. Базой исследования являются 4 школы Латвии: Гимназия северных стран г. Риги, Ильгюциемская средняя школа г. Риги, Вторая Тукумская средняя школа, Валмиерская государственная гимназия.

Теоретической основой нашего исследования послужили следующие работы и концепции:

1. Работы ученых Латвии, которые проанализировали результаты функциональной грамотности в области чтения и факторы, влияющие на развитие интереса к чтению (Tūbele 2011, Stikute 2011, Geske, Grīnfelds, Kangro, Kisel̦ova 2013, Malahova, Budvik̦e, Boge 2014 и др.). 
2. Труды в области критического мышления (Steele, Meredith, Temple 2003, Заир-Бек, Муштавинская 2011 и др.).

3. Психолингвистические теории понимания текста (ван Дейк и Кинч 1988, Залевская 2001 и др.).

4. Лингводидактические теории изучения иностранных языков и развития компетенций в области чтения (Grabe 2002, Nassaji 2002, Salatasi, Akyel 2003, Koppen, Neordman 2003, Соловьева 2006 и др.).

Системообразующим в нашем исследовании стало понятие „стратегии чтения”, под которым понимаются целенаправленные и упорядоченные способы умственных действий при восприятии, осмыслении, отборе и использовании информации, избранной индивидуумом для достижения цели, поставленной перед собой. Овладение стратегиями мы рассматриваем как основу развития функциональной грамотности учащегося в области чтения.

В рамках исследования нами была разработана система овладения стратегиями чтения, которая представлена в серии учебных комплектов „Просто по-русски” (Архангельская, Игнатьева 2008, 2011, 2012, 2015) для 6-9 классов школ Латвии. К основным принципам этой системы относятся:

- жанровая определенность текстов, предлагаемых для чтения,

- коммуникативная оправданность выбора цели (вида) чтения,

- целенаправленное и последовательное развитие речемыслительных способностей учащихся,

- осуществление процесса чтения в ситуативном и личностном контексте,

- взаимосвязь развития компетенций в области чтения с компетенциями в области слушания, говорения и письма.

Поясним каждый из принципов.

\section{Жанровая определенность текстов, предлагаемых для чтения}

Речевой жанр, вслед за Михаилом Михайловичом Бахтиным (1986: 250-275), понимается нами как относительно устойчивые тематические, композиционные и стилистические типы высказываний. Основными факторами их завершенной целостности, неразрывно связанными в органическом целом высказывания, выступают: 1) предметно-смысловая исчерпанность, 2) речевой замысел говорящего или пишущего, 3) типические композиционно-жанровые формы (Бахтин 1986: 269). Следует отметить, что речевой жанр в нашем учебнике выступает в качестве основной единицы обучения. Во-первых, потому что посредством речевых жанров осуществляется 
процесс коммуникации. Во-вторых, любой речевой жанр - это результат развития культурно-речевых традиций. Следовательно, работа с жанрами помогает приобщаться к культурным ценностям. А в-третьих, речевой жанр является удобной лингводидактической моделью текста, своего рода образцом, по аналогии с которым можно создавать собственные тексты и заниматься речетворчеством. Тем самым, предлагая тексты для чтения, в формулировке заданий или в их визуальном оформлении мы всегда называем жанр, с которым предстоит работать. Например: познакомьтесь с сайтом города, прочитайте комментарии в Интернете, примите участие в Интернетфоруме и т. д.

\section{Коммуникативная оправданность в выборе цели и стратегии чтения}

Этот принцип означает, что задания к конкретным текстам зависят от того, с какой целью тексты этих жанров читаются в реальной жизни. Например, в афишах мы обычно ищем конкретную нужную нам информацию. Соответственно, к таким текстам предлагаются задания, направленные на развитие стратегии поискового чтения. На материале статьи, в которой содержится познавательная информация, методически целесообразно совершенствовать стратегию аналитического чтения.

Следующий принцип обусловлен психолингвистической природой чтения как сложного когнитивного процесса восприятия, понимания и запоминания информации.

\section{Целенаправленное развитие речемыслительных способностей учащихся}

Они необходимы для понимания незнакомых слов в тексте, а также для осмысления новой информации. В этой связи в нашей системе заложено последовательное развитие у учащихся представлений об ассоциативно-семантических связях слов, стратегий понимания незнакомых слов и механизмов антиципации. Например, уже после завершения вводно-фонетического курса, наши школьники учатся догадываться о значениях интернациональных слов, а также слов, входящих в общий балто-славянский лексический фонд. Такие слова мы включаем в словарь учебника без перевода на родной язык. Систематическая работа со словообразовательными моделями позволяет осваивать стратегию понимания семантики новых слов с опорой на внутреннюю и внешнюю форму слова. Умения строить прогнозы по поводу содержания текстов совершенствуются в процессе овладения стратегиями опоры на смысловые связи, на собственные фоновые знания и опыт, на здравый смысл и др. 


\section{Осуществление процесса чтения в ситуативном и личностном контексте}

Задания для чтения оформляются в виде определенной ситуации, что предполагает наличие иллюстративного ряда, способного вызвать у учащихся соответствующие ассоциации. Кроме того, чтение текста предваряется заданиями, направленными на актуализацию эмоционального восприятия учащимися темы текста или имеющегося у них опыта. Например, текст к теме „Времена года” (7 класс, второй год обучения) представлен в жанре разговора ребят о любимых и нелюбимых временах года. Текст сопровождается фотографиями участников разговора, а также фотографиями, иллюстрирующими их отношение к разным временам года. В качестве преддекстового задания мы предлагаем посмотреть мультфильм на музыку Пётра Ильича Чайковского „Времена года” и ответить на вопросы: Как вы думаете, какого цвета зима, весна, осень, лето? Почему?

\section{Взаимосвязанное обучение видам речевой деятельности}

Это общий принцип коммуникативной методики, который распространяется и на овладение стратегиями чтения. Общая языковая основа для развития компетенций в области всех видов речевой деятельности создает условия для того, чтобы в переделах определенного концентра подготовить учащихся к полноценному использованию информации, которая получена в результате работы с текстом.

Весь процесс овладения стратегиями чтения был разделён нами на два этапа в зависимости от решаемых дидактических задач.

Первый этап - уровень А1-A1 + (6-7 классы).

Основные методические задачи:

1) Совершенствование техники чтения и развитие артикуляционных, произносительных и интонационных навыков.

2) Развитие умений глобального восприятия информации.

3) Овладение базовыми стратегиями понимания незнакомых слов.

4) Развитие отдельных речемыслительных действий.

Основные жанры текстов: диалоги, полилоги, расписание уроков, комментарии в Интернете, электронное письмо, самопрезентации.

Осваиваемые стратегии чтения: чтение с общим охватом содержания (ознакомительное), поиск необходимой информации (поисковое).

Методы и приемы работы

- с семантикой слов и фраз: поиск знакомых слов, поиск интернациональных слов, поиск сходства со словами родного языка, поиск ключевых слов, синонимические замены (для развития умений перефразирования), 
- c информацией: прогнозирование с опорой на иллюстрации, прогнозирование с опорой на контекст.

Второй этап - уровень А2-A2 + (8-9 классы).

Основные методические задачи:

1) Развитие умений понимать и анализировать информацию.

2) Овладение всем комплексом стратегий понимания незнакомых слов.

Основные жанры: поздравительная открытка, письмо другу, рассказ о событии (история), письмо в журнал, статья из журнала, анкета, эссе, опрос, интервью, рекомендации психологов, информативный (познавательный) текст, интернет-форум, сайт, объявление, афиша, афоризм, анкеты, притча, реклама.

Осваиваемые стратегии чтения: ознакомительное чтение, поисковое, просмотровое, аналитическое, критическое.

\section{Методы и приемы работы:}

- с семантикой слов и фраз: поиск словообразовательных связей, определение грамматических связей, поиск ключевых слов, синонимические замены, перефразирование;

- с информацией: прогнозирование с опорой на заголовок, на собственный опыт, на задания к тексту, на структуру текста (поиск логических связей), установление связей между известным и неизвестным, различение информации (известная - новая, убедительная - неубедительная, основная - дополнительная, важная / полезная - избыточная), исключение избыточной информации, поиск новой информации, проверка гипотез / мнений / фактов.

\section{Заключение}

Представленную лингводидактическую систему овладения стратегиями чтения можно в полной мере назвать коммуникативной и соответствующей компетентностному подходу, так как все ее компоненты ориентированы на включенность читательской активности учащихся в процесс современной коммуникации. Овладевая стратегиями чтения, учащиеся не только развивают умения работать с текстами и собственное мышление, но и осознают способы эффективного чтения и использования информации, что способствует их самопознанию и самоуправлению в процессе получения образования.

Данная лингводидактическая система ещё только проходит апробацию. Однако уже предварительные результаты исследования позволили сделать важный вывод. С одной стороны, у большого количества учащихся (64 \%) развивается интерес к чтению на русском языке (они сами выбирают для себя тексты для чтения и рассказывают о них). С 
другой стороны, чтобы система работала полноценно, надо специально заниматься подготовкой учителей. Для этого при Латвийской ассоциации преподавателей русского языка и литературы (ЛАПРЯЛ) организованы курсы развития профессиональной компетенции учителей.

\section{SUMMARY}

Nowadays, there is a clearly outlined direct correlation between information competences of people and their life quality. One of the most important means for obtaining information is reading. That is why the considerable attention is paid to reading competences in the sphere of the school education.

The aim of the research paper "The System of Mastering Reading Strategies in the Framework of the Course on Russian as a Foreign Language: the Experience of Developing a Textbook" is to develop a linguodidactic system for gaining reading strategies and to present it in the framework of a school textbook in Russian as a foreign language. However, despite the fact that at the dawn of the twenty-first century information and communication technologies are already part of all spheres of our life, a school textbook still remains the main means for learning a foreign language at school. It is particularly important in the period of a paradigm shift in education, since the linguodidactic system of the textbook helps to introduce new approaches and innovative educational technologies into the school practice. These present-day trends in educational development are fully reflected in a number of documents of the Council of Europe ("Lisbon European Council. Presidency Conclusions 2000", "A Memorandum on Lifelong Learning", "European Council Conclusions on the Role of Education and Training in the Implementation of "Europe 2020" Strategy" etc.). All these documents stress the main aim of the education as the students' comprehensive development expressed in their competences. The term competences corresponds to the basic characteristics covering the cognitive, psychomotor and motivational sphere of the individuals and determining their ability to participate in the professional and life situations successfully (L. Spenser, S. Spenser). Therefore, the competence approach is the response put forward by the European Commission's Directorate-General for Education and Culture to the needs of the modern society and reflects the educational policy at schools of the European Union.

In the development of linguo-didactic system of competence development in the reading sphere of Russian as a foreign language at school, we have used the following methods: the analysis of the scientific literature, monitoring the school process and its analysis, testing, questionnaire for students and teachers, conversations. The study base is four schools in Latvia: Grammar School of Nordic Languages (Riga), Il’guciema Secondary School (Riga), Tukums Secondary School No. 2, Valmiera State Gymnasium. 
In our study, we use the term reading strategies as a backbone term which is understood as a targeted and streamlined way of mental abilities in percieving, thinking, selecting and sharing information needed by an individual to achieve the aim in question (L. Vygotsky, T. A. van Dijk and W. Kintsch, R. Oxford, A. Zalevskaya, A. Kangro, Z. Rubene, S. Zair-Bek, I. Mushtavinskaya, O. Andreeva, L. Khromov and others). We consider the term "gaining strategies" as the basic for the students' functional literacy in the sphere of reading.

The main principles of the linguo-didactic system in gaining reading strategies in the course of Russian as a foreign language are

- the genre of the texts proposed for reading;

- the communicative appropriateness of the aim (type) of reading (e. g. reading for main ideas is suggested while reading a billboard, analytical reading is chosen while reading the informative article etc.);

- targeted and consistent development of verbal and cogitative students' abilities (e. g. predicting words, sentences, text fragments with the focus on the non-verbal and verbal context, background knowledge on the given topic, and common sense;

- reading in the situational and personal context;

- interaction of the development of competences among reading, listening, speaking and writing competences.

The proposed system is presented in the textbook by E. Arhangelska and L. Ignatjeva “Simple Russian” („Просто по-русски”, 2008-2015) for Forms 6-9 at Latvian schools.

The whole process of gaining reading strategies was divided into two stages depending on the range of didactic tasks.

The first stage - level A1--A1+ (Forms 6-7). Tasks: 1. Improving reading skills and developing articulation, pronunciation and intonation skills. 2. Developing skills of global perception of information. 3. Learning basic strategies of understanding unknown words. 4. Developing separate verbal and cogitative actions. The reading skills to be learnt: reading for reference and vocabulary, reading for main ideas.

The second stage - level A2-A2 + (Forms 8-9). Tasks: 1. Developing skills to understand and analyse the information. 2. Learning all the strategies of understanding unknown words. The reading skills to be learnt: reading for reference and vocabulary, reading for main ideas, analytical reading, critical reading.

The given linguo-didactic system is currently being piloted. However, the preliminary study findings led to the significant conclusion. On the one hand, a large number of students (64\%) have a growing interest in reading in the Russian language (students choose their reading texts in their own way and tell about them). On the other hand, the specific teacher training is necessary for proper system work. 


\section{СПИСОК ИСТОЧНИКОВ И ЛИТЕРАТУРЫ / LITERATŪRA}

Council Conclusions 2011
Council conclusions on the role of education and training in the implementation of the Europe 2020 strategy $3066^{\text {th }}$. Education, Youth, Culture and Sport Council meeting Brussels, 14 February 2011. Piekluve: https://www.consilium.europa. eu/uedocs/cms_data/docs/ pressdata/en/educ/119282.pdf [Skatìts: 8.01.2017.]

Geske, Grīnfelds, Kangro, Geske, A., Grīnfelds, A., Kangro, A., Kisel̦ova R. (2013) Latvija Kisel̦ova $2013 \quad$ OECD Starptautiskajā skolēnu novērtēšanas programmā 2012 pirmie rezultāti un secinājumi. Rīga: Latvijas Universitāte.

Grabe 2002 Grabe, W. (2002) Reading in a second language. The Oxford handbook of applied linguistics. Kaplan R. B. (Ed.). Oxford: Oxford University Press, p. 49-59.

Koppen, Neordman 2003 Koppen, M. \& Neordman, L. G. M. (2003) Modeling knowledge-based references in story comprehension. Cognitive Science, vol. 27, № 6, p. 875-910.

Lasītprasmes mācīšana Lasītprasmes mācīšana Eiropā: konteksts, rīcībpolitika un prakse, Eiropā 2011 Eiropas komisija. 2011. Piekluve: http://eacea.ec.europa.eu/ education/ eurydice.../documents/thematic_reports/130LV. pdf [Skatīts: 12.12.2016.]

Lisbon European Council Lisbon European Council 23 and 24 march 2000. Presidency 2000 Conclusions. Piekḷve: http://www.europarl.europa.eu/ summits/lis1_en.htm [Skatīts: 2.11.2016.]

Malahova, Budvik̦e, Boge Malahova, L., Budvik̦e, I., Boge I. (2014) Studējošo lasišanas 2014 kompetences atškirības dažãdos vecumposmos. Sabiedrïba, integrācija, izglïtiba. Starptautiskās zinātniskās konferences materiāli. 2014. gada 23.-24. maijs, 1. daḷa. Rēzekne: Rēzeknes Augstskola, 184.-191. lpp.

Memorandum on

Lifelong Learning 2000

A Memorandum on Lifelong Learning. Commission Staff Working Paper, Brussels, 30.10.2000, SEC(2000) 1832. Piekluve: http://arhiv.acs.si/dokumenti/Memorandum_on_ Lifelong_Learning.pdf [Skatìts: 10.12.2016.]

Nassaji 2002

Nassaji, H. (2002) Shema theory and knowledge-based processes in second language reading comprehension. Language Learning, vol. 52, № 2, p. 439-481.

Salatasi, Akyel 2002

Salatasi, R. \& Akyel, A. (2002) Possible effects of strategy instruction on LI and L2 reading. Reading in a Foreign Language, vol. 14., № 1, pp. 1-14. Piekliuve: http: http:// nflrc.hawaii.edu/rfl/April2002/salataci/salataci.pdf [Skatīts: 10.12.2016.]

Stikute $2011 \quad$ Stikute, E. (2011) Latviešu literatūras apguves problēmas mūsdienu izglītības kontekstā. Sabiedrïba, integrācija, izglìtỉba. Starptautiskās zinātniskās konferences materiāli. 2011. gada 27.-28. maijs, 2. daḷa. Rēzekne: Rēzeknes Augstskola, 369.-379. lpp.

Temple, Steele, Meredith Temple, Ch., Steele, J. L, Meredith, K. S. (2003) Initiation in the (2003) for Developing Critical Thinking. 2nd Edition. Supplement of the journal DidacticaPro, 1(7), Chiúinău. 
Tūbele 2011

Архангельская, Игнатьева 2008, 2011, 2012, 2015

Бахтин 1986

Дейк, Кинч 1988

Заир-Бек, Муштавинская 2011

Залевская 2001

Соловьева 2006

Спенсер, Спенсер 2010
Tūbele, S. (2011) Lasītinteresi veicinošie un kavējošie faktori. Sabiedrïba, integrācija, izglitïba. Starptautiskās zinātniskās konferences materiāli. 2011. gada 27.-28. maijs, 1. daḷa. Rēzekne: Rēzeknes Augstskola, 519.-526. lpp.

Архангельская, Э., Игнатьева, Л. (2008; 2011; 2012; 2015) Просто по-русски. Krievu valoda. Учебный комплект для 6-9 классов. Rìga: Retorika-A.

Бахтин, М. М. (1986) Эстетика словесного творчества. 2-е изд. Москва: Искусство.

Дейк, ван Т. А., Кинч, В. (1988) Стратегии понимания связного текста. Новое в зарубежной лингвистике, вып. 23. Москва: Прогресс, с. 153-211.

Заир-Бек, С. И., Муштавинская, И. В. (2011) Развитие критического мышления на уроке. 2-е изд., дораб. Москва: Просвещение.

Залевская, А. А. (2001) Текст и его понимание. Тверь: Твер. гос. университет.

Соловьева, М. В. (2006) Стратегии понимания иноязычного дискурса с опорой на выводные знания. Языковой дискурс в сочиальной практике: Мат. Межрегиональн. науч.практич. конф. Тверь: Твер. гос. университет, с. 259-263.

Спенсер, Л. М., Спенсер, С. М. (2010) Компетенции на работе. Модели максимальной эффективности работы. Перевод с англ. Москва: издательство ГИППО. 